\title{
Improving the Decision-Making Process in the Higher Learning Institutions via Electronic Records Management System Adoption
}

\author{
Muaadh Mukred ${ }^{1 *}$, Zawiyah M. Yusof ${ }^{1}$, Umi Asma' Mokhtar', Ali S. Sadiq ${ }^{2}$, Burkan Hawash ${ }^{1}$, \\ and Waleed Abdulkafi Ahmed ${ }^{3}$ \\ ${ }^{1}$ Faculty of Information Science and Technology, Universiti Kebangsaan Malaysia \\ 43600 Bangi, Selangor, Malaysia \\ [e-mail: muaadh@ukm.edu.my, zawiy@ukm.edu.my,umimokhtar@ukm.edu.my,burkan,hawash@yahoo.com] \\ ${ }^{2}$ School of Mathematics and Computer Science, University of Wolverhampton \\ Wulfruna Street Wolverhampton, WV1 1LY, UK \\ [e-mail: ali.sadiq@wlv.ac.uk] \\ ${ }^{3}$ The International Modern Arabic School, Jalan P14k, Presint 14, 62050 Putrajaya \\ Wilayah Persekutuan, Putrajaya, Malaysia \\ [e-mail: waleed@imas.edu.my] \\ *Corresponding author: Muaadh Mukred
}

Received November 23, 2020; revised December 26, 2020; accepted January 12, 2021; published January 31, 2021

\begin{abstract}
Electronic Records Management System (ERMS) is a computer program or set of applications that is utilized for keeping up to date records along with their storage. ERMS has been extensively utilized for enhancing the performance of academic institutions. The system assists in the planning and decision-making processes, which in turn enhances the competencies. However, although ERMS is significant in supporting the process of decision-making, the majority of organizations have failed to take an initiative to implement it, taking into account that are some implementing it without an appropriate framework, and thus resulted in the practice which does not meet the accepted standard. Therefore, this study identifies the factors influencing the adoption of ERMS among employees of HLI in Yemen and the role of such adoption in the decision-making process, using the Unified Theory of Acceptance and Use of Technology (UTAUT) along with Technology, Organization and Environment (TOE) as the underpinning theories. The study conducts a cross-sectional survey with a questionnaire as the technique for data collection, distributed to 364 participants in various Yemeni public Higher Learning Institutions (HLI). Using AMOS as a statistical method, the findings revealed there are significant and positive relationships between technology factors (effort expectancy, performance expectancy, IT infrastructure and security), organizational factors (top management support, financial support, training, and policy),environmental factors (competitiveness pressure, facilitating conditions and trust) and behavioral intention to adopt ERMS, which in return has a significant relationship with the process of decision-making in
\end{abstract}


HLI. The study also presents a variety of theoretical and empirical contributions that enrich the body of knowledge in the field of technology adoption and the electronic record's domain.

Keywords: Decision-Making Process, UTAUT, Electronic Records Management System, Information System Management, Institutions of Higher Learning, Adoption

\section{Introduction}

In the field of education, technology has had a significant contribution to transforming traditional learning and teaching methods into the current approach, which involves the requirement for information access. Information should be available for the students at any time required to assist with the tools they need to achieve their academic goals $[1,2]$. Technology has also contributed to providing information before making well-informed decisions. Decision-making issues are commonplace in different educational areas, particularly the management aspect, where most of the decisions are made from the viewpoint of conjecture that is based on primary data. These issues have to be resolved by making informed decisions that require detailed information evaluation [2-5].

Nowadays many administrators recognize the importance of having accurate and accessible information to support the decisions that improve day-to-day operations, as well as long-range strategic planning. The abundance of systems makes it difficult to find the relevant, exact, and useful information necessary available to the higher education decision-making process. Not all information can be considered as records until they are proven genuine and authentic. Besides, these records must be comprehensive, available, accessible, and secured [6, 7].

In higher education institutions, e-records have been widely used, for it contains information needed for the efficient and effective running of the educational sector, provision of optimum services, and reinforcement of management decision-making while ensuring the implementation of continuous policy. Recorded information generates knowledge, and when processed, helps to make an informed and timely decision. Moreover, students' records are crucial education resources upon which strategies can be set, and performance can be evaluated and improved [8-10].

Although e-records are central for decision-making, problems arise as to whether the records are accessible when needed [10].

In general, decision-making support services in higher education institutions are crucial in facilitating effective performance evaluation. The process of decision-making in these institutions, especially in developing countries, has been rife with complexity. Decisions are made by individuals who are in-charge and hold the knowledge and experience in distinct areas, and those that depend on perceived accurate information $[11,12]$.

Therefore, e-records have a key role to play in achieving the objectives of the organization, including HLI, within which the efficient functioning of the organization is rendered difficult without ERMS implementation [13, 14]. E-records management is deemed to be one of the key public management pillars as the organization's activities revolve around accessing information that the records contain [4, 15-21]. In this regard, ERMS refers to electronic 
management of e-records and non-e-records, using computer equipment coupled with software in distinct premises within which records are managed [11].

HLI administration could face critical outcomes and risks when their decisions are not based on the information contained in e-records $[22,23]$. ERMS reinforces the process of decision making among organizations [24, 25], and tools should reinforce this to steer clear of adverse effects from glitches [26].

It is important to consider that organizations may only be able to reap the full advantages of systems (e.g., ERMS) when the users accept it and understand it fully, and when the drivers of its successful adoption are determined for improved implementation [27]. According to [2830], upon determining the acceptance/resistance factors of technology among employees, a satisfactory return on investment can be made possible on the IT implemented applications. Also, the lack of a supporting framework for the adoption, absorption, and management of ERMS could culminate in the deletion, misplacement or loss of significant records in the process of gathering, storing, retrieving and disposing of records and this could go against the governance process of the country's digital capabilities.

ERMS adoption can also bring about the effective and efficient retrieval of information and enable validity examination of data quality, research, and eventually, for reaching informed decisions [28].

In literature, the majority of studies concentrated on drivers of ERMS adoption in sectors other than the education sector [31]. Additionally, resistance towards ERMS adoption among the learning institutions in developing nations was noted by [32,33]. Such resistance, coupled with the slow adoption rate and the novelty of ERMS, poses several challenges in the public education institutions when it comes to system implementation [22, 34, 35].

It is pertinent to understand the resistance of ERMS adoption among employees to accelerate its acceptance in educational institutions. Based on these arguments, this study identifies the drivers of employees' ERMS adoption in the educational sector in Yemen.

Studies dedicated to ERMS are still scarce; most studies that are available have focused on technology adoption theories and models [13, 29]. According to [36], the application of theory/model in a specific cultural context may differ from one culture to the next, as some variables that are important for one may not be for others. Therefore, in the present study, the authors attempt to determine the drivers of ERMS adoption in HLI in Yemen and the effect of ERMS on the decision-making process.

The remaining sections of the paper are organized in the following way; first, relevant literature to the study is reviewed. The study presents a theoretical framework and the development of hypotheses. It then provides a description of the methodology and empirical findings. The study is concluded with the overall discussion of the proposed model, the study implications and limitations as well as future avenues of research.

\section{Review of Literature}

An ERMS refers to a computer program or set of programs that are utilized for keeping abreast of records and their storage. It can also be used for the management of the development and maintenance of the record in the scheme of classification, retention usage and disposal of schedules, as well as management of records access and use [37].

Studies that have been conducted to examine ERMS in education are still lacking, and hence, this study reviews past relevant literature to pinpoint the literature gap. It seems appropriate because the ERMS general application among organizations is similar to that in the field of education. Thus, what works for general organizations may also be applied in the 
educational institutions, like HLI, in the Yemeni context.

The primary objective of forming records in organizations has to do with the preservation of information for future use and transactions. Records contain organizational accountability, protect the evidence that indicates its activities, and enable timely administrative information access, ensuring that valuable information can be stored and preserved. [38] explained that such records could be used as evidence of the transactions made by the organization.

In addition, effective e-records form the platform of good government and serve to organize policies, transactions, and activities of governance and functions as an effective information source that can be used to bring about decisions and accountability [38].

In the developing nations, ERMS implementation to date has been notably lagging, but this does not mean that the system fails in increasing the government's efficiency and effectiveness, facilitating transparency and accountability in making decisions and enhancing the provision of public services. This should be highlighted instead of the challenges faced during the implementation of the system, which has been noted to be innumerable irrespective of the nature of the country. In the context of developing countries, lack of training, and user interface design are two of the major indicators that hinder successful ERMS implementation, as evidenced in the study conducted by [39].

Additionally, [40] revealed that within organizations and its departments, ERMS had been made almost mandatory owing to the dynamic demand for information. In this regard, the system saves time and boosts transparency, although the policy has to be developed to add more documents in the system.

In a related empirical study, [41] found that developing nations are mostly lacking the capacity to tackle the e-records management challenges because of lack of policy and legislation, standardization, authenticity, capacity for development, physical infrastructure and professionals that are skilled on the know-how of record-keeping and unaware government authorities that need training on e-records management.

It is irrefutable that ERMS is a paramount system, but in the education sector, HLIs still lack awareness of how important it is. According to [42], in Nigeria, three of the surveyed universities gave no preference to ERMS, indicating that Nigeria has still not managed to implement e-records because of weak legislative support and the lack of framework. In Uganda, the study dedicated to Ugandan Higher Education by [43] found issues in records management that sometimes lead to students being refused permission to graduate.

In a related study, [44] explained that regardless of the importance of recordkeeping to good governance, studies focused on the topic are still scarce. Also, [22] revealed that South African and Malawian universities should be examined in light of their record-keeping in order so that a framework for records and documentation can be developed for management.

Moreover, literature has also indicated that the majority of educational institutions in the developing nations are still facing numerous challenges in e-records and document management despite the efforts that have been taken to improve the governance systems. Records management is lacking in terms of the policy, digital records capacity, records management unit, senior management support, education and training of users, storage, retrieval, and disposition of documents in relevant systems and procedures [13].

[45] referred to IT adoption as the level to which potential adopters think that adopting IT would minimize their efforts in task completion. Adoption has also been defined as the innovation use that appears to be the top course of action [46] and the initial decision and intention towards using innovation [47]. More importantly, the adoption of ERMS plays a major role in the provision of educational services, ensuring that services and provided effectively, which positively affects their delivery. The process initiates with the awareness of 
technology among adopters and ends with the adoption and use of the said technology among the users [48].

In the same line of argument, the user's intention is described by the Theory of Reasoned Action (TRA) and Theory of Planned Behavior as the level of effort that the user expects to exert for goal achievement [49]. The majority of studies of this caliber adopted UTAUT to determine the determinants of the intention of users towards adopting new IT [50-52]. One such study conducted by [53] focused on the case of Bangladesh's e-Health adoption among physicians. The authors made use of a cross-sectional survey to examine the determinants of system adoption.

In fact, in many nations, there is a spread of awareness of the production of significant enhancements of the whole educational system with the innovation adoption [54]. The adoption of ERMS has also been evidenced to contribute to the education provision, consisting of different processes that enhance organizations' effectiveness and performance and its achievement of objectives.

More importantly, studies of ERMS in the education sector revealed that the adoption of technology, particularly ERMS, is still in its infancy $[29,55,56]$, with most of the cases focused on the healthcare sector. Based on the barriers to ERMS adoption enumerated by studies, the major barriers are three; individual-related barriers, organization-related barriers and technology-related barriers. Nevertheless, research on the subject based on theory, specifically those about the characteristics of ERMS and decision-making process, are still few and far between.

[57] urged more studies to be carried out to investigate the adoption of new technology in the context of HLI to transform students into global leaders.

According to the above review of prior studies, this study intends to fill the gap in the literature by examining the acceptance and adoption of ERMS among HLI employees in Yemen, and accordingly, the primary research question is as follows; What are the major factors that influence ERMS adoption in HLI in developing countries?

Finally, literature findings [58-60] validate the successful explanation of UTAUT (70\%) of the variance in the behavioral intention of individuals, whereas the preceding models, such as TAM2, were only able to predict $40 \%$. Added to the above, UTAUT appears to be more suitable to be utilized for the examination of IS adoption in large-sized firms and institutions as it has been widely utilized in studies that tackled adoption of technology - studies with similar objectives as the present one.

\section{Theoretical Framework and Hypotheses Development}

To answer the primary research question in the present study, and based on the suggestions and recommendations of previous researchers $[50,60]$, the most significant user acceptance and behavioral model, which is the UTAUT, is adopted for the identification of the determinants of ERMS adoption in the Yemeni context.

In this regard, [61] referred to models as the engines that create conceptual frameworks, whereas theories are the ones that create theoretical frameworks. Social science researchers begin with models before addressing concepts representing the pinpointed research problem in the subject matter, after which data is gathered to establish the relationship between the concepts. Ultimately, concepts become theoretical structures as they build theory and are measurable - where measurement is the core of operationalization. In contrast to theories that can explain and predict, models merely provide descriptions of the phenomenon. Also, theories are examined via propositions/hypotheses with the help of a suitable method that 
matches the model/theory [61].

Intention towards using new technologies and their actual usage have been examined in the literature using various theories including Innovation Diffusion Theory [46]; Theory of Reasoned Action [62]; Technology Acceptance Model [63]; Theory of Planned Behavior [49]; combined TAM-TPB [64]; Motivational Model [65]; Social Cognitive Theory [66]; Unified Model of E-government Adoption [50, 52].

The development of the UTAUT model was made possible by an exhaustive analysis of the different preceding models to gain a unified perception of the user's acceptance [67, 68]. It was indicated that the UTAUT is capable of clarifying as high as $70 \%$ of the variation in intention behavior [59], and it has been extensively utilized in different fields, with the inclusion of ERMs and the sector of education [69].

Based on prior studies' review of ERMS in the education sector, it is notable that the top used constructs are 11 and they are postulated in the development of this study's conceptual research model depicted in Fig. 1. The 11 factors, namely effort expectancy, performance expectancy, IT infrastructure, security, top management support, financial support, training, policy, competitiveness pressure, facilitating conditions, and trust, determine the behavioral intention and use behavior. The proceeding sections provide the development of hypotheses to measure the factors mentioned.

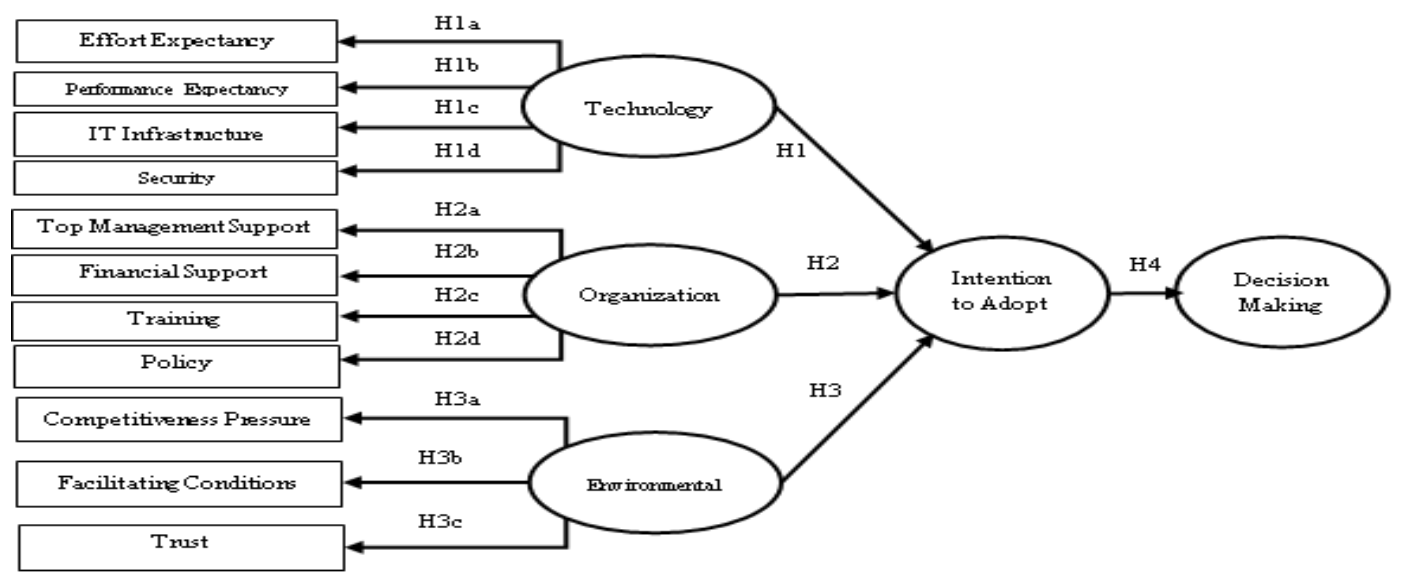

Fig. 1. ERMS Adoption Framework with Hypothesis

The UTAUT by [70] is used as the underpinning model of this study to examine the intention of ERMS adoption based on the factors that are dimensions of technology and organization. In addition to this underpinning theory, [71] TOE framework is adopted as taxonomy as it has been widely applied to classify factors influencing behavioral intention towards the system. [72] supported TOE as an effective taxonomy for the variables categorization, but not as an integrated conceptual framework or a fully developed theory. [73] explained that TOE variables differed from one context to the next, enabling the inclusion of some variables for the enrichment of the categorization.

In other words, this study uses a combination of a taxonomic framework to categorize ERMS and to propose a framework that can facilitate decision-making in HLI in Yemen. The framework is used to examine the influential factors that are significant in ERMS adoption. The findings of this study are expected to contribute to the field of taxonomy development and to highlight the factors and their categorizations within which their relationships are examined. 
The literature indicates sub-important factors that could influence the intention towards adopting ERMS, which relates to the environment and are not mentioned in UTAUT, and such characteristics are related to technical factors. Thus, this study considers explicitly environmental, namely competitiveness pressure, facilitating conditions, and trust, to be examined.

The first level of the framework (dimensions of factors) is displayed in Fig. 1. The dimensions of technology, organization, and environment are considered as the exogenous variables that are assumed to have a direct influence on the adoption of ERMS, which represents the endogenous variable. In the second framework level, i.e., the adoption stage, it consists of intention towards ERMS adoption and is comprised of endogenous variables wherein which such adoption falls between the exogenous and endogenous variables and directly impacts the process of decision-making. As for the third level, i.e., the system use, it consists of the decision-making process (dependent variable). [63] also referred to the dependent variable as the outcome construct. The proposed study framework is based on UTAUT and TOE, as mentioned. The three dimensions and their factors are detailed in the following sub-sections.

The TOE framework is a taxonomy for categorizing variables [72], and it is not a representation of an integrated conceptual framework or a well-developed theory. The variables within the TOE framework may differ from one context to the next [73], and thus some other variables have to be incorporated into it for enrichment.

Hence, in the present study, the TOE framework is employed to determine the groups of extracted factors. Table 1 shows the hypothesis of the study.

Table 1. Hypothesis

\begin{tabular}{|l|l|}
\hline No & Hypothesis \\
\hline \hline H1 & Technological factors have a positive influence on the adoption of ERMS in HLI. \\
\hline H1a & Effort expectancy has a positive and significant influence on the adoption of ERMS in HLI. \\
\hline H1b & $\begin{array}{l}\text { Performance expectancy has a positive and significant influence on the adoption of ERMS } \\
\text { in HLI. }\end{array}$ \\
\hline H1c & IT infrastructure has a positive and significant influence on the adoption of ERMS in HLI. \\
\hline H1d & Security has a positive and significant influence on the adoption of ERMS in HLI. \\
\hline H2 & $\begin{array}{l}\text { Organizational factors have a positive and significant influence on the adoption of ERMS in } \\
\text { HLI. }\end{array}$ \\
\hline H2a & $\begin{array}{l}\text { Top management support has a positive and significant influence on the adoption of ERMS } \\
\text { in HLI. }\end{array}$ \\
\hline H2b & Financial support has a positive and significant influence on the adoption of ERMS in HLI. \\
\hline H2c & Training has a positive and significant influence on the adoption of ERMS in HLI. \\
\hline H2d & The policy has a positive and significant influence on the adoption of ERMS in HLI. \\
\hline H3 & $\begin{array}{l}\text { Environmental Factors have a positive and significant influence on the adoption of ERMS } \\
\text { in HLI. }\end{array}$ \\
\hline H31 & $\begin{array}{l}\text { Competitiveness Pressure has a positive and significant influence on the adoption of ERMS } \\
\text { in HLI. }\end{array}$ \\
\hline H3b & $\begin{array}{l}\text { Facilitating Conditions has a positive and significant influence on the adoption of ERMS in } \\
\text { HLI. }\end{array}$ \\
\hline H3c & Trust has a positive and significant influence on the adoption of ERMs in HLI. \\
\hline H4 & ERMS adoption significantly relates to the decision-making process in HLI. \\
\hline
\end{tabular}




\section{Methodology}

A cross-sectional survey questionnaire method was adopted in this study for data collection. The survey was divided into six sections. The first, second, and third sections measured technological factors, organizational factors, and environmental factors, respectively. In the fourth section, the items measured intention towards ERMS adoption, and in the fifth one, the items measured intention towards ERMS role in the process of decision making. In the sixth and final section, the demographic characteristics of the participants were obtained and entered a descriptive statistic test to shed light on the characteristics of the sample.

The survey items were measured on a Likert scale because the scale is characterized by easy management, ease of answering and it provides instrument reliability [74]. Specifically, a 5-point Likert scale was used to mitigate the potential of measurement error and to prevent the violation of normality and data distribution assumptions. Therefore, in Parts A to E, the items were measured on a 5-point Likert scale with the following legend: 1 depicts strongly disagree, 2 depicts disagree, 3 depicts neutral, 4 depicts agree and 5 depicts strongly agree.

The validity of the measures was ensured by developing the measurement items for each latent construct from prior literature. The detailed items of every construct in this study, along with the sources from which they were taken, are tabulated in Table 2.

Table 2. Summary of Constructs with Measurement Items

\begin{tabular}{|c|c|}
\hline Factor & Adapted from \\
\hline \hline Effort Expectancy & {$[63,75]$} \\
\hline Performance Expectancy & {$[76]$} \\
\hline IT Infrastructure & {$[77-79]$} \\
\hline Security & {$[80]$} \\
\hline Top Management Support & {$[81]$} \\
\hline Financial Support & {$[82,83]$} \\
\hline Training & {$[84]$} \\
\hline Policy & {$[41]$} \\
\hline Competitiveness Pressure & {$[85-87]$} \\
\hline Facilitated Conditions & {$[68,88]$} \\
\hline Trust & {$[89,90]$} \\
\hline Intention to adopt ERMS & {$[91]$} \\
\hline Decision Making Process & {$[92,93]$} \\
\hline
\end{tabular}

\section{Results}

Under this section, the overall results of the study are presented.

\subsection{Demographic Characteristics of the Sample}

Table 3 contains the demographic characteristics of the respondents. The analyzed data from the surveys were provided by 364 respondents, from which 339 (93.1\%) constituted male respondents, and the remaining 25 (6.9\%) constituted female respondents. With regard to their ages, 115 respondents $(31.6 \%)$ were in the age category of 30-40 years constituting the majority of the respondents, while 2 respondents were in the age category of less than 20 years, constituting the least respondents. As for the respondents' education level, most of the respondents (77\%) held bachelor's degrees, while the fewest (3\%) held a diploma. 
Table 3. Summary of the Personal Characteristics of the Respondents

\begin{tabular}{|c|c|c|c|c|}
\hline Variable & Types & Frequency & Percentage & Valid Percent \\
\hline \multirow{3}{*}{ Gender } & Male & 339 & 93.1 & 93.1 \\
\hline & Female & 25 & 6.9 & 6.9 \\
\hline & Total & 364 & 100 & 100 \\
\hline \multirow{7}{*}{ Age } & Less than 20 years & 2 & 0.5 & 0.5 \\
\hline & $20-24$ years & 15 & 4.1 & 4.1 \\
\hline & 25-29 years & 102 & 28 & 28 \\
\hline & $30-40$ years & 115 & 31.6 & 31.6 \\
\hline & $41-50$ years & 113 & 31 & 31 \\
\hline & Over 50 years & 17 & 4.7 & 4.7 \\
\hline & Total & 364 & 100 & 100 \\
\hline \multirow[t]{6}{*}{ Qualification } & Diploma & 11 & 3 & 3 \\
\hline & Bachelor & 261 & 71.7 & 71.7 \\
\hline & Master & 80 & 22 & 22 \\
\hline & $\mathrm{PhD}$ & 12 & 3.3 & 3.3 \\
\hline & Total & 364 & 100 & 100 \\
\hline & Lecturer & 250 & 68.7 & 68.7 \\
\hline \multirow{2}{*}{ Job } & $\begin{array}{l}\text { Administration } \\
\text { Staff }\end{array}$ & 106 & 29.1 & 29.1 \\
\hline & Other & 8 & 2.2 & 2.2 \\
\hline \multirow{8}{*}{ Experience } & Total & 364 & 100 & 100 \\
\hline & Less than 2 years & 10 & 2.7 & 2.7 \\
\hline & $2-4$ years & 92 & 25.3 & 25.3 \\
\hline & 4-6 years & 131 & 36 & 36 \\
\hline & $6-8$ years & 79 & 21.7 & 21.7 \\
\hline & 8-10 years & 35 & 9.6 & 9.6 \\
\hline & More than 10 years & 17 & 4.7 & 4.7 \\
\hline & Total & 364 & 100 & 100 \\
\hline
\end{tabular}

\subsection{Measurement Model}

The evaluation of the measurement model was done in two parts that involved the measurement model fit test and the condition of goodness-of-fit of the same. The evaluation examined the uni-dimensionality, validity, and reliability of the measurement model, and the first one was done through item-deletion/estimation of a free parameter. The validity of the model, on the other hand, was estimated by conducting convergent, construct, and discriminant validity tests.

In addition to the above, the assessment of reliability was conducted by testing internal reliability, construct reliability, and obtaining average variance extracted (AVE), with the cutoff of reliability, weight, and fit indices kept in consideration. The following table lists the cutoff value of the standardized estimates of the factor loadings in terms of regression weight, covariance as well as the reliability values. 
SEM was also used to conduct confirmatory and exploratory modeling, as both were suitable to test and develop the theory. This study developed the framework in two major steps; step one involved the proposed framework structure development by combining the tested and validated models and including them in one comprehensive framework, while step two involved the examination of the framework's goodness-of-fit.

The factor loadings of the items ranged from 0.67 to 0.84 , with an effect size that exceeded 0.4 , indicating the presence of discriminant validity. The framework results are tabulated in Table 5. As for the correlation value between the exogenous constructs (refer to Fig. 2), it was less than 0.85, which indicates that redundant items were absent from the framework and that discriminant validity was established. The validity of the framework was obtained through convergent validity, using the AVE equation. All the values of AVE were 0.50 or higher.

Touching upon the CR values, they were obtained by using Awang [94]'s formula, and the condition was such that the values have to be equal to or higher than 0.60 to establish construct and composite reliability. In this study, the CR value exceeded 1.96, with Cronbach's alpha of every factor tested for internal reliability and were found to exceed 0.70 , indicating good reliability.

Considering the construct reliability of the framework, this study obtained the goodnessof-fit estimation, and the results are tabulated in Table 4. From the table, it is clear that the normed chi-square obtained fell between 2 and 5 (2.80), with the R2 standard coefficients of the correlations significant at $\mathrm{p}<0.000$, and absolute fit parsimony of 0.57 (by RMSEA), which is lower than 0.08. As for the incremental fit indices, they were 0.945 ( $\geq 0.9)$ for CFI, 0.910 $(\geq 0.8)$ for GFI, and $0.887(\geq 0.8)$ for adjusted GFI. The obtained values indicated that the proposed framework satisfied the criteria laid down for goodness-of-fit indices in literature, which means that empirical data fit is established.

On the whole, the structural model indices satisfied the suggested values, confirming the excellent fit of the model, with validity and reliability tested and validated.

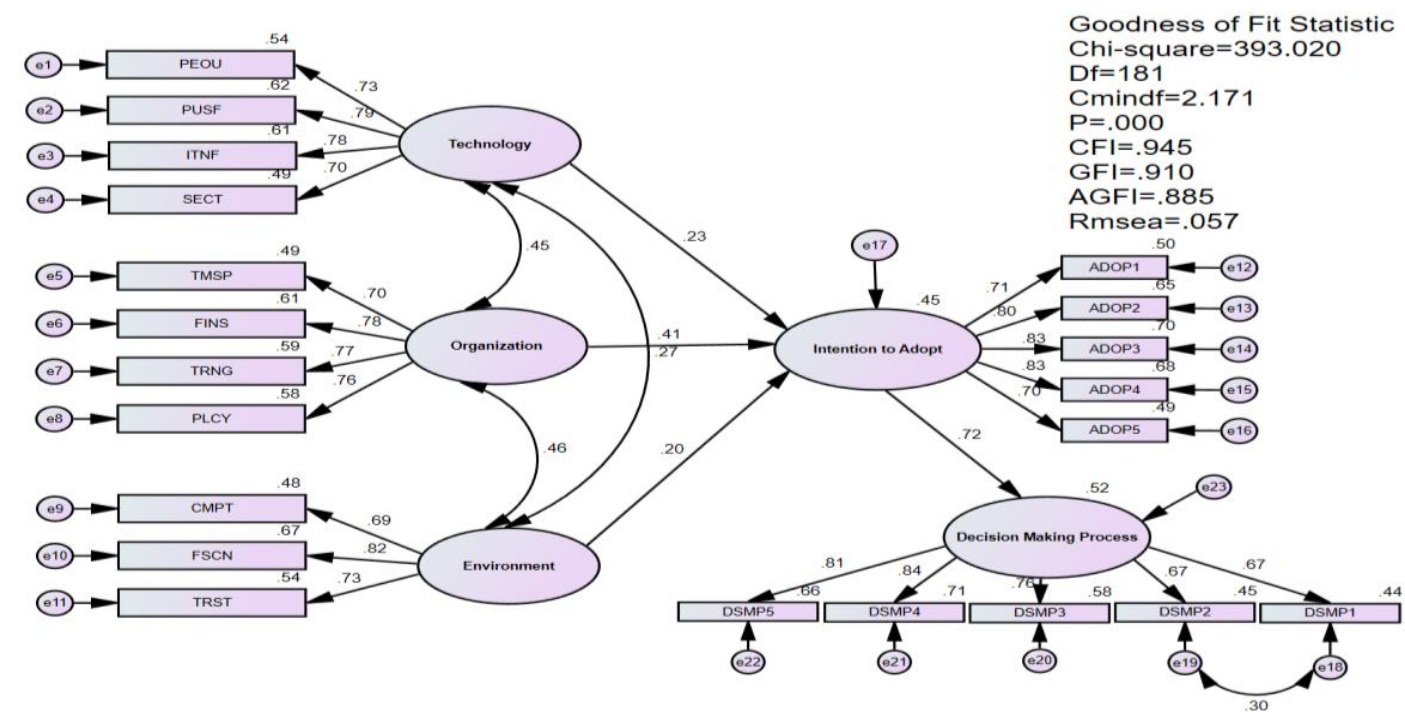

Fig. 2. Framework Validation Results 
Table 4. Full SEM Measurement of the Fitness of the ERMS Framework

\begin{tabular}{lllcl}
\hline Measurement & \multicolumn{2}{c}{ Recommended } & Fitness measure & Conclusion \\
\hline$X^{2}$ value & & & 393.020 & Acceptable \\
{$\left[R E r X^{2} / \mathrm{df}\right.$} & $<3$ & {$[95]$} & 2.171 & Acceptable \\
CFI & $\geq 0.9$ & {$[96]$} & 0.945 & Acceptable \\
GFI & $\geq 0.8$ & {$[97]$} & 0.910 & Acceptable \\
AGFI & $\geq 0.8$ & {$[95]$} & 0.885 & Acceptable \\
RMSEA & $<0.8$ & {$[95]$} & 0.057 & Acceptable \\
\hline
\end{tabular}

\subsection{Hypotheses Testing}

Based on the analysis findings, the structural model's excellent fit is established (refer to Table 5). The findings also showed that the path loadings of the technological factors, organizational factors, and environmental factors all had a positive and significant influence on the intention towards the adoption of ERMS. The hypotheses testing of the path loadings also indicated that intention towards the adoption of ERMS positively and significantly influenced the decisionmaking process in HLI. Table 5 lists the summary of the hypotheses results.

Table 5. Standardized Regression Weight of the ERMS Framework

\begin{tabular}{|c|c|c|c|c|c|c|c|c|}
\hline Constructs & Path & Factors & Estimate & S.E & C.R. & P- & AVE & CR \\
\hline Effort Expectancy & $\leftarrow$ & Technology & 0.734 & 1 & & & \multirow{4}{*}{0.563} & \multirow{4}{*}{0.837} \\
\hline $\begin{array}{l}\text { Performance } \\
\text { Expectancy }\end{array}$ & $\leftarrow$ & & 0.786 & 0.082 & 13.508 & $* * *$ & & \\
\hline IT Infrastructure & $\leftarrow$ & & 0.781 & 0.078 & 13.440 & $* * *$ & & \\
\hline Security & $\leftarrow$ & & 0.697 & 0.086 & 12.141 & $* * *$ & & \\
\hline $\begin{array}{l}\text { Top Management } \\
\text { Support }\end{array}$ & $\leftarrow$ & \multirow[t]{4}{*}{ Organization } & 0.702 & 1 & & & \multirow{4}{*}{0.570} & \multirow{4}{*}{0.841} \\
\hline Financial Support & $\leftarrow$ & & 0.784 & 0.097 & 13.097 & $* * *$ & & \\
\hline Training & $\leftarrow$ & & 0.771 & 0.087 & 12.931 & $* * *$ & & \\
\hline Policy & & & 0.761 & 0.103 & 12.796 & $* * *$ & & \\
\hline $\begin{array}{l}\text { Competitiveness' } \\
\text { Pressure }\end{array}$ & $\leftarrow$ & \multirow[t]{3}{*}{ Environmental } & 0.692 & 1 & & & \multirow{3}{*}{0.563} & \multirow{3}{*}{0.794} \\
\hline $\begin{array}{l}\text { Facilitating } \\
\text { Conditions }\end{array}$ & $\leftarrow$ & & 0.820 & 0.102 & 11.812 & $* * *$ & & \\
\hline Trust & $\leftarrow$ & & 0.734 & 0.104 & 11.468 & $* * *$ & & \\
\hline Adop1 & $\leftarrow$ & \multirow{5}{*}{$\begin{array}{l}\text { Intention to } \\
\text { Adopt }\end{array}$} & 0.707 & 1 & & & \multirow{5}{*}{0.604} & \multirow{5}{*}{0.883} \\
\hline Adop2 & $\leftarrow$ & & 0.804 & 0.085 & 14.341 & $* * *$ & & \\
\hline Adop3 & $\leftarrow$ & & 0.834 & 0.083 & 14.833 & $* * *$ & & \\
\hline Adop4 & $\leftarrow$ & & 0.826 & 0.080 & 14.706 & $* * *$ & & \\
\hline Adop5 & $\leftarrow$ & & 0.703 & 0.077 & 12.610 & $* * *$ & & \\
\hline
\end{tabular}




\begin{tabular}{lllllllll} 
Quality & $\rightarrow$ & Decision & 0.666 & 1 & & & & \\
Effectiveness & $\rightarrow$ & Making & 0.671 & 0.075 & 13.509 & $* * *$ & & \\
Accuracy & $\rightarrow$ & Process & 0.763 & 0.104 & 12.486 & $* * *$ & 0.570 & 0.868 \\
Performance & $\rightarrow$ & & 0.844 & 0.098 & 13.469 & $* * *$ & & \\
Accountability & $\rightarrow$ & & 0.813 & 0.090 & 13.122 & $* * *$ & & \\
\hline
\end{tabular}

\section{Discussion}

The analysis findings not only revealed the excellent fit of the structural model but also revealed that the hypotheses testing of the path loadings of technological factors had a positive and significant influence on intention towards the adoption of ERMS. Fig. 2 depicts the direction and magnitude of such a relationship, indicating support for $\mathrm{H} 1$ that proposed a positive influence of technological factors on the adoption of ERMS in HLI.

Based on the obtained findings, technological factors should be considered when determining the adoption of ERMS in HLI as it influences the operational, tactical, and strategic levels of the organization and the individuals working in the institutions. Concerning past literature, [98] revealed the influence of technological factors on ERMS adoption, and as such, HLI institutions should keep technological factors into top consideration for successful adoption of ERMS.

More specifically, performance expectancy as a technological factor was revealed to be important to ERMS adoption as it enhances effectiveness, increases productivity and facilitates timely task achievement, makes work easier and provides more control over work. The results of the analysis concerning this construct supported its significant positive influence on the adoption of ERMS (C.R. $=13.508, \mathrm{p}<0.001)$. Therefore, the sub-hypothesis that proposed a positive and significant influence of Performance Expectancy on the adoption of ERMS is supported.

The second construct of the technological dimension is IT infrastructure, which is a technological aspect that provides the extensive infrastructure in terms of interconnectivity level, higher flexibility in including e-records, facilitating user's remote access to centralized data, and making data available at all times. The results of the analysis, in this case, supported a significant positive influence of IT infrastructure on system adoption (C.R. $=13.440$, $\mathrm{p}<0.001)$. Thus, H1c, which posits the positive influence of IT infrastructure on ERMS adoption in HLI, is supported. HLI should thus take IT infrastructure into consideration for the proper ERMS system adoption, and when upgraded, the system should easily include software applications that can be utilized throughout different platforms. This study is supported by [99] and [100].

Moving on to the security aspect of technology, the present study results support its influence on the successful adoption of ERMS in HLI, as similarly evidenced by prior studies such as, [101] and [40]. Table 5 contains the quantitative analysis results, and from the table, it is evident that the factor obtained the critical ratio of 12.141 with significant $p<0.001$. Thus, the overall results showed support for H1d.

This study examined the influence of organizational factors on the adoption of ERMS in HLI, from the urging of prior studies that addressed the same (e.g., [102]). Thus, the significance of the organizational factors when adopting any IS is confirmed. The results show that, from the hypothesis testing of the path loading of organizational factors, a positive value of 0.41 was obtained, signifying that organizational factors do have a significant influence over ERMS adoption (refer to Fig. 2), and supporting H2, which posited the positive influence 
of organizational factors on ERMS adoption in HLI.

More specifically, from the organizational factors, top management support was revealed to have a significant and positive effect on intention towards ERMS adoption. According to the findings, top management support is the only way to get started with their commitment and compliance with the management departments. Top management support and involvement in the adoption of ERMS lead to successful adoption. This supports H2a that posited the positive influence of top management support on intention towards adopting ERMS. Other studies in literature like [103] and [104] also supported this result. Therefore, top management support does facilitate the ERMS adoption success as management participates in system adoption and provide their commitment to keeping such adoption as a top priority.

Financial support is another organizational factor that plays a key role in a system purchase, payment incentives, infrastructure security, and equipment, and this holds for HLI. Based on the quantitative analysis results, a critical ratio value of 13.097 , with significant $p<0.001$, was obtained. Thus $\mathrm{H} 2 \mathrm{~b}$ is supported. This shows that financial support should be kept into consideration when implementing ERMS adoption, as suggested by [83].

The training factor was also examined in this study in light of its influence on the ERMS adoption in educational institutions. The respondents showed that training should be provided to meet the requirements of users and to customize materials for their tasks, and include the entire business task in the system. The respondents also underlined the system's tracking of the training levels and sufficiency of the employees. As for the empirical results, SEM analysis showed a significant and positive influence of training on intention towards ERMS adoption (C.R. = 12.931, p<.001) in Table 5, and as such, H2c is supported. This finding was also reported by prior studies such as [105] and [106].

The final organizational factor is policy, and in this study, HLI policy should establish ERMS adoption in that the policy should promote compliance with legal and regulatory mandates, it should be clear, it should cover the system functions, and it should be implementable and cost-effective. The SEM analysis results showed a significant and positive influence of policy on intention towards ERMS adoption (C.R. $=12.796, p<.001$ ) (refer to Table 5). In other words, the policy has a key role in successful ERMS adoption, and as such, HLI that are inclined towards system implementation should have a policy supporting such implementation. Other studies in literature support this result (e.g., [107] and [108]). Therefore, HLI needs to establish and promote the policy dedicated to ERMS for the creation and management of accurate, dependable, useable records to support decision-making and business functions when required.

Concerning the environmental factors, the results showed that they influence the adoption of ERMS among individuals and organizations at the level of operations, tactics, and strategies. This study examined the Environmental factors, including competitiveness pressure, facilitating conditions and trust, and the relationships between the factors and ERMS adoption intention were all significant and positive, and as such, $\mathrm{H} 3$ is supported.

More specifically, competitiveness pressure was confirmed to have a positive influence on ERMS adoption in HLI, indicating support for sub-hypothesis 3a based on the SEM analysis results. In other words, for the smooth running of the system, ERMS must have competitiveness pressure for HLI adoption. The same holds for prior study results that supported the importance of competitiveness pressure, including [8, 9]. HLI has to concentrate on competitiveness pressure when they adopt ERMS and to ensure it is present and available to system users.

Facilitating conditions is another factor under the environmental dimension, and based on the responses, it has a major role in intention towards ERMS adoption. The results of the SEM 
analysis showed a critical ratio of 11.812 significant at $\mathrm{p}<0.001$, indicating support for the subhypothesis $3 \mathrm{~b}$. The responses underlined the significance of facilitating conditions to informed decision-making, as reported in prior studies. HLI should strive to promote ERMS adoption by ensuring facilitating conditions for successful and proper adoption.

Lastly, the trust factor reflects the timeliness of the service provision, where service is accurate and complete. Trust analysis obtained a critical ratio of 11.468 , at a significant $p<.001$ (refer to Table 5 and Fig. 2). This evidences that sub-hypothesis $3 \mathrm{c}$ is supported. This is reinforced by the finding that trust has a positive and significant influence on the adoption of ERMS in HLI, and thus, such institutions have to focus on the factor for smooth and easy system adoption.

As for the process of decision making, the findings indicated its positive influence on the adoption of ERMS adoption, with the direction of effect from the latter to the former. In other words, ERMS makes it possible to reach quality, effective and accurate informed decisions, which boost performance and accountability. As for the present study, responses indicated that perceived ERMS role in decision making and promotion of high quality, effective, and accurate decisions lead to the enhancement of performance and the facilitation of accountability.

Overall, the entire findings supported the framework of the ERMS adoption among HLI for effective decision making. The framework was found to be implementable, comprehensive and complete and will lead to successful adoption and improve the decision making process. These findings are also supported by [11], who revealed the major role that ERMS plays in the decision-making process, and thus when ERMS is adopted among HLI, the above factors have to be taken into top consideration.

\section{Contribution}

The major contribution that this study provides is to highlight the management of e-records systems in HLI to promote the effective process of decision-making, particularly in a developing nation like Yemen. The study findings contribute to theory and practice about ERMS and the factors that influence its adoption and use.

ERMS adoption studies of its relationship with the decision-making process are still lacking, and thus, the findings of this study contribute both to theory and practice as detailed in the following sub-sections.

This study has several implications for both theory and practice when it comes to the adoption of ERMS, particularly in its promotion of informed decision making. Theoretically, this study contributes in several ways.

First, it contributes to the development of the ERMS framework considering the decisionmaking process among HLI, and second, it minimizes the literature gap by examining the underlying factors in the education sector that affects ERMS adoption. The study also examined the issues found within the factors and sub-factors affecting the phenomenon.

The third contribution is the provision of a required basis for the ERMS effective adoption as the study highlights the important factors influencing such adoption for decision-making among institutions of higher learning. Fourth, with the findings, the study contributes new information to the field of ERMS, particularly in developing nations. The study also underlined ERMS functions that reinforce the process of decision-making in institutions and provides insight into avenues that future studies can follow. The study also detailed the complex relationships among factors and the adoption of ERMS. Studies that examined ERMS adoption in literature did not use a combination of UTAUT and TOE as the underpinning 
theories. Overall, the study framework addressed the successful adoption of ERMS with three dimensions (technological, organizational, and Environmental). This study extended prior studies relating to IS theories that have not been used to examine the ERMS context.

Considering the above contributions to theory, it is evident that the aim is to develop a system supporting HLI decision making through a proposed ERMS successful adoption framework. The framework's objective is to provide insight into system adoption to conduct an effective decision-making process in HLI $s$ in a developing country like Yemen. In this regard, several practical implications can be provided for organizations and policymakers. This study explained the importance of ERMS and its key role in the process of decision making in HLI, and thus, it may contribute to practice in the following ways.

First, organizations can take note of the findings of this study concerning the factors that influence the adoption of ERMS to leverage them in their effective and smooth adoption. The findings can promote awareness among organizations as the way ERMS supports the process of decision making. Three dimensions were dealt with, namely technological, organization, and Environmental dimensions, and their influence on the adoption of ERMS. Management can concentrate on the dimensions' factors to hone best practices of adoption via the development of a checklist for reference. The examined factors can also be referenced for the allocation of resources.

The second practical contribution is to the ERMS stakeholders who can use the findings to help them administer their functions in their professional capacities. The findings of intention towards ERMS adoption among users also shed light on the users' intention towards such adoption and the contribution to proper adoption.

Stated clearly, different stakeholders have to collaborate to achieve effective adoption of ERMS. In this study, first-hand information was obtained from the ERMS users, who are frontline practitioners that can actively play a role in the implementation. Such users are practitioners who are experts in their field and are knowledgeable of the factors that influence ERMS adoption. They can contribute to developing, maintaining, and enhancing ERMS and in collaborating with their peers on how to bring about decision processes through the system.

Additionally, the study framework provides insights into the beneficiaries' perceptions of the significant factors that affect the adoption of ERMS. With the mismatch between the framework and the ideas of the policymakers, the latter can tweak the framework and make modifications to adopt measures accordingly, while focusing on the factors for performing maintenance. The policymakers may also evaluate the factors for effective implementation of policies concerning ERMS.

In sum, the present study contributes to empirical as well as practical ideas when it comes to ERMS adoption for HLI s decision-making process. Future studies are suggested to replicate the study to support the ERMS adoption outcomes and the relevant factors in different contexts.

\section{Conclusion}

This study has examined the factors affecting ERMS adoption in the context of HLIs in Yemen, using the UTAUT underpinning theory and TOE model for factors taxonomy. Academicians and managers of HLI were the major players in the adoption of ERMS initiative, and as such, their adoption and use precipitate the completion of effective adoption in the educational sector. The underpinning model was used to examine the effects of factors, divided into three dimensions (technological, organizational, and environmental), on the adoption of ERMS in HLI, and in turn, on the decision-making process of the institutions. All the proposed hypotheses were supported, and the study findings had theoretical and practical implications 
that can be taken into top consideration for the smooth adoption of ERMS and its enhancement of the decision-making process in institutions of higher learning. Further research is called for to build on the findings of this study, particularly to investigate the relationships that might exist between, on one hand, each of the determinants of ERMS adoption and the institutions performance, on the other hand, their possible relationships with decision making performance. Although the investigation of the present study involved many ERMS factors that affect employees' intention to adopt ERMS in the public HPE sector, determination of this influence is only limited to these investigated factors while there are some other factors that might affect the intention as previously mentioned in the literature. Therefore, future research should investigate the influence of these factors on users' attitudes and intention based on the same theory and other information system theories. Moreover, the sample of the study was collected from HPE governmental institutions in Yemen, which represent only one type of educational models in Yemen. Since there are many types of educational models with different universities, the sample of this study is not sufficient to represent all types and levels. Hence, future research should focus on more types and levels of educational systems to cover ERMS for wider set of universities in Yemen.

\section{Acknowledgement}

We would like to thank Faculty of Information Science and Technology, Universiti Kebangsaan Malaysia by giving the authors an opportunity to conduct this research, This work was supported by Universiti Kebangsaan Malaysia Research Grant [GUP-2019-61 and DCP2017-013/6]

\section{References}

[1] C. Turney, D. Robinson, M. Lee, and A. Soutar, "Using technology to direct learning in higher education: The way forward?," Active Learning in Higher Education, vol. 10, pp. 71-83, 2009. Article (CrossRef Link)

[2] D. Uerz, M. Volman, and M. Kral, "Teacher educators' competences in fostering student teachers' proficiency in teaching and learning with technology: An overview of relevant research literature," Teaching and Teacher Education, vol. 70, pp. 12-23, 2018. Article (CrossRef Link)

[3] B. Hawash, U. A. Mokhtar, and M. Z. Yusof, "The primarily study of Electronic Records Management System (ERMS) for Yemen Oil and Gas Corporation (YOGC) Subsidiaries," in Proc. of 2019 International Conference on Cybersecurity (ICoCSec), pp. 13-19, 2019. Article (CrossRef Link)

[4] M. Mukred and Z. M. Yusof, "The Performance of Educational Institutions Through the Electronic Records Management Systems: Factors Influencing Electronic Records Management System Adoption," International Journal of Information Technology Project Management (IJITPM), vol. 9, no. 3, pp. 34-51, 2018. Article (CrossRef Link)

[5] A. E. Nwaomah, "Records Information Management Practices: A Study on a Faith Based University," International Journal for Innovation Education and Research, vol. 5, no. 11, pp. 87102, 2017. Article (CrossRef Link)

[6] M. Mukred, Z. M. Yusof, F. M. Alotaibi, U. A. Mokhtar, and F. Fauzi, "The Key Factors in Adopting an Electronic Records Management System (ERMS) in the Educational Sector: A UTAUT-Based Framework," IEEE Access, vol. 7, pp. 35963-35980, 2019. Article (CrossRef Link)

[7] M. Mukred, Z. M. Yusof, and F. M. Alotaibi, "Ensuring the Productivity of Higher Learning Institutions Through Electronic Records Management System (ERMS)," IEEE Access, vol. 7, pp. 97343-97364, 2019. Article (CrossRef Link) 
[8] M. Mukred, Z. M. Yusof, U. A. Mokhtar, and F. Fauzi, "Taxonomic framework for factors influencing ERMS adoption in organisations of higher professional education," Journal of Information Science, vol. 45, no. 2, pp. 139-155, 2018. Article (CrossRef Link)

[9] P. U. Akor and J. Udensi, "An assessment of record management system in establishment division of two universities in Nigeria," International Letters of Social and Humanistic Sciences, no. 2, pp. 97-109, 2013. Article (CrossRef Link)

[10] B. Hawash, U. A. Mokhtar, Z. M. Yusof, M. Mukred, and W. Ali, "Intention to Adopt Electronic Records Management System in the Oil and Gas Sector in Yemen," International Journal of Advanced Trends in Computer Science and Engineering, vol. 9, no. 5, pp. 6959-6971, 2020. Article (CrossRef Link)

[11] B. Hawash, U. Asma'Mokhtar, Z. M. Yusof, and M. Mukred, "The adoption of electronic records management system (ERMS) in the Yemeni oil and gas sector," Records Management Journal, vol. 30, no. 1, pp. 1-22, 2020. Article (CrossRef Link)

[12] T. Wright, "Information culture in a government organization: Examining records management training and self-perceived competencies in compliance with a records management program," Records Management Journal, vol. 23, no. 1, pp. 14-36, 2013. Article (CrossRef Link)

[13] J. R. Baron and A. Thurston, "What Lessons Can Be Learned From the US Archivist's Digital Mandate for 2019 And Is There Potential For Applying Them in Lower Resource Countries?," Records Management Journal, vol. 26, no. 2, 2016. Article (CrossRef Link)

[14] M. Mukred and Z. M. Yusof, "The DeLone-McLean Information System Success Model for Electronic Records Management System Adoption in Higher Professional Education Institutions of Yemen," in Proc. of International Conference of Reliable Information and Communication Technology, pp. 812-823, 2017. Article (CrossRef Link)

[15] M. Mukred, Z. M. Yusof, U. Asma'Mokhtar, and N. A. Manap, "Electronic Records Management System Adoption Readiness Framework for Higher Professional Education Institutions in Yemen," International Journal on Advanced Science, Engineering and Information Technology, vol. 6, no. 6, pp. 804-811, 2016. Article (CrossRef Link)

[16] M. Mukred and Z. M. Yusof, "Factors Influencing the Adoption of Electronic Records Management (ERM) for Decision Making Process at Higher Professional Education (HPE)'s Institutions," in Proc. of the $1^{\text {st }}$ ICRIL-International Conference on Innovation in Science and Technology (IICIST 2015), 2015. Article (CrossRef Link)

[17] M. Mukred and Z. M. Yusof, "The Role of Electronic Records Management (ERM) for supporting Decision making Process in Yemeni Higher Professional Education (HPE): A Preliminary Review," Jurnal Teknologi, vol. 73, pp. 117-122, 2015. Article (CrossRef Link)

[18] M. Mukred and Z. M. Yusof, "Electronic Records Management and Its Importance for Decision making Process in Yemeni Higher Professional Education (HPE): A Preliminary Review," in Proc. of the $1^{\text {st }}$ International Conference of Recent Trends in Information and Communication Technologies (IRICT 2014), 2014. Article (CrossRef Link)

[19] K. K. Adu, "Framework for digital preservation of electronic government in Ghana," Ph.D. dissertation, University of South Africa, Pretoria, 2015.

[20] J. Amo, "The Role of Records Management Practices in Improving Decision Making in Public Hospitals: The Case of Ashanti Bekwai Municipal Hospital," Ph. D. dissertation, University of Ghana, Accra, Ghana, 2016.

[21] R. Osakwe, "The Efficiency of Managing School Records by Secondary School Principals in Delta State, Nigeria," Annals of Modern Education, vol. 5, pp. 72-80, 2013. Article (CrossRef Link)

[22] N. O. Regina, "Management of school records by secondary school principals in Delta state, Nigeria," The Social Sciences, vol. 6, no. 1, pp. 40-44, 2011. Article (CrossRef Link)

[23] E. Şuşnea, "Improving decision making process in universities: A conceptual model of intelligent decision support system," Procedia-Social and Behavioral Sciences, vol. 76, pp. 795-800, 2013. Article (CrossRef Link)

[24] A. G. Desta, M. du Preez, and P. Ngulube, "Factors affecting the information-seeking behaviour of postgraduate students at the University of South Africa Ethiopia Regional Learning Centre," Information Development, vo1. 35, no. 3, p. 0266666917744824, 2017. Article (CrossRef Link) 
[25] A. Hossain, R. Quaresma, and H. Rahman, "Investigating factors influencing the physicians' adoption of electronic health record (EHR) in healthcare system of Bangladesh: An empirical study," International Journal of Information Management, vol. 44, pp. 76-87, 2019. Article (CrossRef Link)

[26] O. Mosweu, K. J. Bwalya, and A. Mutshewa, "A probe into the factors for adoption and usage of electronic document and records management systems in the Botswana context," Information Development, vol. 33, no. 1, pp. 97-110, 2017. Article (CrossRef Link)

[27] F. Mohammed, O. Ibrahim, and N. Ithnin, "Factors influencing cloud computing adoption for egovernment implementation in developing countries: Instrument development," Journal of Systems and Information Technology, vol. 18, no. 3, pp. 297-327, 2016. Article (CrossRef Link)

[28] W.-S. Tzeng, K.-M. Kuo, P. C. Talley, H.-C. Chen, and J.-J. Wang, "Do ePortfolios Contribute to Learners' Reflective Thinking Activities?: A Preliminary Study of Nursing Staff Users," Journal of medical systems, vol. 39, pp. 1-10, 2015. Article (CrossRef Link)

[29] C. Ghering, J. B. Caruso, and D. Gift, "Electronic Records Management: Today’s High Stakes," ECAR Research Bulletin, vol. 8, pp. 1-12, 2010. Article (CrossRef Link)

[30] B. E. Asogwa, "The challenge of managing electronic records in developing countries: Implications for records managers in sub Saharan Africa," Records Management Journal, vol. 22, no. 3, pp. 198-211, 2012. Article (CrossRef Link)

[31] M. D. Logue and J. A. Effken, "Validating the personal health records adoption model using a modified e-Delphi," Journal of advanced nursing, vol. 69, no. 3, pp. 685-696, 2013. Article (CrossRef Link)

[32] M. Mukred, Z. M. Yusof, N. A. B. M. Noor, B. K. Kayode, and R. Al-Duais, "The Role of Cloud Electronic Records Management System (ERMS) Technology in the Competency of Educational Institutions," in Proc. of International Conference of Reliable Information and Communication Technology, 2019, pp. 936-946. Article (CrossRef Link)

[33] V. Venkatesh and X. Zhang, "Unified theory of acceptance and use of technology: US vs. China," Journal of global information technology management, vol. 13, pp. 5-27, 2010. Article (CrossRef Link)

[34] Y. M. Chae, K. B. Yoo, E. S. Kim, and H. Chae, "The adoption of electronic medical records and decision support systems in Korea," Healthcare informatics research, vol. 17, no. 3, pp. 172-177, 2011. Article (CrossRef Link)

[35] R. Eusoff and Z. M. Yusof, "Development of records management system for matriculation colleges in Malaysia," Asia-Pacific Journal of Information Technology and Multimedia, vol. 11, 2011. Article (CrossRef Link)

[36] H. Z. Henriksen and K. V. Andersen, "Electronic records management systems implementation in the Pakistani local government," Records Management Journal, vol. 18, no. 1, pp. 40-52, 2008. Article (CrossRef Link)

[37] S. K. Sharma, "Adoption of e-government services: The role of service quality dimensions and demographic variables," Transforming Government: People, Process and Policy, vol. 9, no. 2, pp. 207-222, 2015. Article (CrossRef Link)

[38] A. A. Aziz, Z. M. Yusof, U. A. Mokhtar, and D. I. Jambari, "Establishing Policy for the Implementation of Electronic Document and Records Management System in Public Sector in Malaysia: The Influencing Factors," Advanced Science Letters, vol. 23, no. 11, pp. 10732-10736, 2017. Article (CrossRef Link)

[39] B. Eze Asogwa, "The readiness of universities in managing electronic records: A study of three federal universities in Nigeria," The Electronic Library, vol. 31, no. 6, pp. 792-807, 2013. Article (CrossRef Link)

[40] M. B. Muhenda and E. K. Lwanga, "Managing Records in Higher Education Institutions in Uganda: Can Human Resource Policies Salvage the Situation?," World Journal of Social Sciences, vol. 2, no. 2, pp. 74-83, 2012. Article (CrossRef Link)

[41] K. K. Adu and P. Ngulube, "Key threats and challenges to the preservation of digital records of public institutions in Ghana," Information, Communication \& Society, vol. 20, no. 8, pp. 11271145, 2017. Article (CrossRef Link) 
[42] L. A. Phillips, R. Calantone, and M.-T. Lee, "International technology adoption: Behavior structure, demand certainty and culture," Journal of Business \& Industrial Marketing, vol. 9, no. 2, pp. 1628, 1994. Article (CrossRef Link)

[43] E. M. Rogers, Diffusion of innovations: Simon and Schuster, NY, USA, 2010.

[44] E. Proctor, H. Silmere, R. Raghavan, P. Hovmand, G. Aarons, A. Bunger, R. Griffey, and M. Hensley, "Outcomes for implementation research: conceptual distinctions, measurement challenges, and research agenda," Administration and Policy in Mental Health and Mental Health Services Research, vol. 38, pp. 65-76, 2011. Article (CrossRef Link)

[45] K. Renaud and J. Van Biljon, "Predicting technology acceptance and adoption by the elderly: a qualitative study," in Proc. of the 2008 annual research conference of the South African Institute of Computer Scientists and Information Technologists on IT research in developing countries: riding the wave of technology, 2008, pp. 210-219. Article (CrossRef Link)

[46] I. Ajzen, "The theory of planned behavior," Psychology \& Health, vol. 26, no. 9, pp. 1113-1127, 2011. Article (CrossRef Link)

[47] Y. K. Dwivedi, N. P. Rana, A. Jeyaraj, M. Clement, and M. D. Williams, "Re-examining the unified theory of acceptance and use of technology (UTAUT): Towards a revised theoretical model," Information Systems Frontiers, pp. 719-734, 2017. Article (CrossRef Link)

[48] J. Li, A. Talaei-Khoei, H. Seale, P. Ray, and C. R. MacIntyre, "Health care provider adoption of eHealth: systematic literature review," Interactive journal of medical research, vol. 2, no. 1, 2013. Article (CrossRef Link)

[49] N. P. Rana, Y. K. Dwivedi, B. Lal, M. D. Williams, and M. Clement, "Citizens' adoption of an electronic government system: towards a unified view," Information Systems Frontiers, vol. 19, pp. 549-568, 2017. Article (CrossRef Link)

[50] M. R. Hoque, A. Albar, and J. Alam, "Factors influencing physicians' acceptance of e-health in developing country: An empirical study," International Journal of Healthcare Information Systems and Informatics (IJHISI), vol. 11, no. 1, pp. 58-70, 2016. Article (CrossRef Link)

[51] J. Cheon, S. Lee, S. M. Crooks, and J. Song, "An investigation of mobile learning readiness in higher education based on the theory of planned behavior," Computers \& Education, vol. 59, no. 3, pp. 1054-1064, 2012. Article (CrossRef Link)

[52] B. C. Atulomah, "Perceived records management practice and decision making among university administrators in Nigeria," Library Philosophy and Practice, vol. 1, p7-13, 2011. Article (CrossRef Link)

[53] A. Tarhini, K. Hone, and X. Liu, "Factors affecting students' acceptance of e-learning environments in developing countries: a structural equation modeling approach," International Journal of Information and Education Technology, vol. 3, pp. 54-59, 2013. Article (CrossRef Link)

[54] A. A. Hariri, "Adoption of learning innovations within UK universities: validating an extended and modified UTAUT model," Ph. D. dissertation, University of Warwick, United Kingdom, 2014.

[55] N. Oye, N. Iahad, and N. A. Rahim, "The history of UTAUT model and its impact on ICT acceptance and usage by academicians," Education and Information Technologies, vol. 19, pp. 251-270, 2014. Article (CrossRef Link)

[56] J. Khalilzadeh, A. B. Ozturk, and A. Bilgihan, "Security-related factors in extended UTAUT model for NFC based mobile payment in the restaurant industry," Computers in Human Behavior, vol. 70, pp. 460-474, 2017. Article (CrossRef Link)

[57] O. Mosweu, K. Bwalya, and A. Mutshewa, "Examining factors affecting the adoption and usage of document workflow management system (DWMS) using the UTAUT model: Case of Botswana," Records Management Journal, vol. 26, no. 1, pp. 38-67, 2016. Article (CrossRef Link)

[58] P. Ngulube, E. R. Mathipa, and M. T. Gumbo, "Theoretical and conceptual frameworks in the social and management sciences," Addressing research challenges: making headway for developing researchers, pp. 43-66, 2015. Article (CrossRef Link)

[59] M. Fishbein and I. Ajzen, Belief, attitude, intention and behavior: An introduction to theory and research, Baylor University, Waco, Texas, USA, 1975.

[60] F. D. Davis, "Perceived usefulness, perceived ease of use, and user acceptance of information technology," MIS quarterly, vol. 13, no. 3, pp. 319-340, 1989. Article (CrossRef Link) 
[61] S. Taylor and P. A. Todd, "Understanding information technology usage: A test of competing models," Information systems research, vol. 6, no. 2, pp. 85-188, 1995. Article (CrossRef Link)

[62] F. D. Davis, R. P. Bagozzi, and P. R. Warshaw, "User acceptance of computer technology: a comparison of two theoretical models," Management science, vol. 35, no. 8, pp. 982-1028, 1989. Article (CrossRef Link)

[63] A. Bandura, Social foundation of thought and action: A social-cognitive view, Englewood Cliffs, India: Sage Publication, 1986.

[64] Y. K. Dwivedi, M. A. Shareef, A. C. Simintiras, B. Lal, and V. Weerakkody, "A generalised adoption model for services: A cross-country comparison of mobile health (m-health)," Government Information Quarterly, vol. 33, no. 1, pp. 174-187, 2016. Article (CrossRef Link)

[65] V. Venkatesh, M. G. Morris, G. B. Davis, and F. D. Davis, "User acceptance of information technology: Toward a unified view," MIS quarterly, vol. 27, no. 3, pp. 425-478, 2003. Article (CrossRef Link)

[66] C. M. Barrette, "Usefulness of technology adoption research in introducing an online workbook," System, vol. 49, pp. 133-144, 2015. Article (CrossRef Link)

[67] V. Venkatesh, J. Y. Thong, and X. Xu, "Consumer acceptance and use of information technology: extending the unified theory of acceptance and use of technology," MIS quarterly, vol. 36, no. 1, pp. 157-178, 2012. Article (CrossRef Link)

[68] L. G. Tornatzky, M. Fleischer, and A. Chakrabarti, The processes of technological innovation; Issues in organization and management series,New York, USA: Lexington Books, 1990.

[69] J. Dedrick and J. West, "An exploratory study into open source platform adoption," in Proc. of the $37^{\text {th }}$ Annual Hawaii International Conference on System Science, 2004. Article (CrossRef Link)

[70] Y.-M. Wang, Y.-S. Wang, and Y.-F. Yang, "Understanding the determinants of RFID adoption in the manufacturing industry," Technological forecasting and social change, vol. 77, pp. 803-815, 2010. Article (CrossRef Link)

[71] A. Bryman, Social research methods, Oxford University, UK: Oxford university press, 2015.

[72] H. Wang, J. E. Chung, N. Park, M. L. McLaughlin, and J. Fulk, "Understanding online community participation: A technology acceptance perspective," Communication Research, vol. 39, pp. 781801, 2012. Article (CrossRef Link)

[73] E. Kiraz and D. Ozdemir, "The relationship between educational ideologies and technology acceptance in pre-service teachers," Educational Technology \& Society, vol. 9, no. 2, pp. 152-165, 2006. Article (CrossRef Link)

[74] T. A. Byrd and E. Turner, "An exploratory analysis of the information technology infrastructure flexibility construct," Journal of Management Information Systems, vol. 17, no. 1, pp. 167-208, 2000. Article (CrossRef Link)

[75] P. P. Tallon and A. Pinsonneault, "Competing perspectives on the link between strategic information technology alignment and organizational agility: insights from a mediation model," Mis Quarterly, vol. 35, no. 2, pp. 463-486, 2011. Article (CrossRef Link)

[76] H. Chen, R. H. Chiang, and V. C. Storey, "Business intelligence and analytics: from big data to big impact," MIS quarterly, vol. 36, no. 4, pp. 1165-1188, 2012. Article (CrossRef Link)

[77] A. Da Veiga, N. Martins, and J. H. Eloff, "Information security culture-validation of an assessment instrument," Southern African Business Review, vol. 11, no. 1, pp. 147-166, 2007. Article (CrossRef Link)

[78] B. S. Ragu-Nathan, C. H. Apigian, T. Ragu-Nathan, and Q. Tu, "A path analytic study of the effect of top management support for information systems performance," Omega, vol. 32, no. 6, pp. 459471, 2004. Article (CrossRef Link)

[79] E. W. Jamoom, V. Patel, M. F. Furukawa, and J. King, "EHR adopters vs. non-adopters: Impacts of, barriers to, and federal initiatives for EHR adoption," Healthcare, vol. 2, no. 1, pp. 33-39, 2014. Article (CrossRef Link)

[80] F.-C. Tung, S.-C. Chang, and C.-M. Chou, "An extension of trust and TAM model with IDT in the adoption of the electronic logistics information system in HIS in the medical industry," International journal of medical informatics, vol. 77, pp. 324-335, 2008. Article (CrossRef Link) 
[81] J. K. Stratman and A. V. Roth, "Enterprise resource planning (ERP) competence constructs: twostage multi-item scale development and validation," Decision Sciences, vol. 33, no. 4, pp. 601-628, 2002. Article (CrossRef Link)

[82] M. Ş. Ensari, "A research related to the factors affecting competitive strategies of SMEs operating in Turkey," International Journal of Business and Social Science, vol. 7, no. 2, pp. 73-80, 2016. Article (CrossRef Link)

[83] I. Nabhani, A. Daryanto, and A. Rifin, "Mobile broadband for the farmers: a case study of technology adoption by cocoa farmers in Southern East Java, Indonesia," AGRIS on-line Papers in Economics and Informatics, vol. 8, no. 2, pp. 111-120, 2016. Article (CrossRef Link)

[84] E. Scornavacca, "An investigation of the factors that influence user acceptance of mobile information systems in the workplace," Victoria University of Wellington, 2010. Article (CrossRef Link)

[85] T. Zhou, Y. Lu, and B. Wang, "Integrating TTF and UTAUT to explain mobile banking user adoption," Computers in human behavior, vol. 26, no. 4, pp. 760-767, 2010. Article (CrossRef Link)

[86] M. A. Shareef, V. Kumar, U. Kumar, and Y. K. Dwivedi, "e-Government Adoption Model (GAM): Differing service maturity levels," Government information quarterly, vol. 28, no. 1, pp. 17-35, 2011. Article (CrossRef Link)

[87] S. E. Colesca, "Understanding trust in e-government," Engineering Economics, vol. 63, 2009. Article (CrossRef Link)

[88] R. Yalcinkaya, Police officers' adoption of information technology: A case study of the Turkish POLNET system: Citeseer, Ph. D. Dissertation, University of North Texas, Texas, USA, 2007.

[89] D. L. Nixon, "Barriers to electronic medical records (EMR) adoption by selected primary care physicians in Arizona: A case study," Ph. D. dissertation, Capella University, MI, Minnesota, 2009.

[90] S. Larson, "Information Systems and strategic decisions: A literature Review," SAIS 2009 Proceedings, 2009. Article (CrossRef Link)

[91] Z. Awang, Structural equation modeling using AMOS graphic: Penerbit Universiti Teknologi MARA, 2012.

[92] P. Barrett, "Structural equation modelling: Adjudging model fit," Personality and Individual Differences, vol. 42, pp. 815-824, 2007. Article (CrossRef Link)

[93] B. M. Byrne, "Structural equation modeling with AMOS: basic concepts, applications, and programming (multivariate applications series)," New York: Taylor \& Francis Group, 2010.

[94] N. Gorla, "An assessment of information systems service quality using SERVQUAL," The Data Base for Advances in Information Systems, vol. 42, no. 3, pp. 14-60, 2011. Article (CrossRef Link)

[95] D. A. Ludwick and J. Doucette, "Adopting electronic medical records in primary care: lessons learned from health information systems implementation experience in seven countries," International journal of medical informatics, vol. 78, pp. 22-31, 2009. Article (CrossRef Link)

[96] S. Petter, W. DeLone, and E. R. McLean, "Information systems success: The quest for the independent variables," Journal of Management Information Systems, vol. 29, no. 4, pp. 7-62, 2014. Article (CrossRef Link)

[97] Y. T. Park and J. Lee, "Factors affecting electronic medical record system adoption in small Korean hospitals," Healthcare informatics research, vol. 20, pp. 183-190, 2014. Article (CrossRef Link)

[98] Y. Zheng, K. Zhao, and A. Stylianou, "The impacts of information quality and system quality on users' continuance intention in information-exchange virtual communities: An empirical investigation," Decision Support Systems, vol. 56, pp. 513-524, 2013. Article (CrossRef Link)

[99] A. Avgar, L. M. Hitt, and P. Tambe, "The effects of organizational factors on healthcare IT adoption costs: Evidence from New York nursing homes," in Proc. of the $43^{\text {rd }}$ Hawaii International Conference on System Sciences, pp. 1-9, 2010. Article (CrossRef Link)

[100] Z. Yang, A. Kankanhalli, B.-Y. Ng, and J. T. Y. Lim, "Analyzing the enabling factors for the organizational decision to adopt healthcare information systems," Decision Support Systems, vol. 55, no. 3, pp. 764-776, 2013. Article (CrossRef Link)

[101] M. Sumner, "EMR Implementation: Lessons Learned from ERP," in Proc. of International Workshop on Enterprise Systems, pp. 19-44, 2015. Article (CrossRef Link) 
[102] A. Boonstra and M. Broekhuis, "Barriers to the acceptance of electronic medical records by physicians from systematic review to taxonomy and interventions," BMC health services research, vol. 10, p. 231, 2010. Article (CrossRef Link)

[103] K. M. Cresswell, D. W. Bates, and A. Sheikh, "Ten key considerations for the successful implementation and adoption of large-scale health information technology," Journal of the American Medical Informatics Association, vol. 20, pp. e9-e13, 2013. Article (CrossRef Link)

[104] J. S. Ancker, Y. Barrón, M. L. Rockoff, D. Hauser, M. Pichardo, A. Szerencsy, and N. Calmen, "Use of an electronic patient portal among disadvantaged populations," Journal of general internal medicine, vol. 26, pp. 1117-1123, 2011. Article (CrossRef Link)

[105] P. Otto and D. Nevo, "Electronic health records: A simulation model to measure the adoption rate from policy interventions," Journal of Enterprise Information Management, vol. 26, pp. 165182, 2013. Article (CrossRef Link)

[106] B. Hawash, Y. I. Abuzawayda, U. A. Mokhtar, Z. M. Yusef and M. Mukred, "Digital Transformation In The Oil And Gas Sector During Covid-19 Pandemic," International Journal of Management (IJM), vol. 11, no. 12, pp. 725-735, 2020. Article (CrossRef Link)

[107] K. M. Cresswell, D. W. Bates, and A. Sheikh, "Ten key considerations for the successful implementation and adoption of large-scale health information technology," Journal of the American Medical Informatics Association, vol. 20, pp. e9-e13, 2013. Article (CrossRef Link)

[108] J. S. Ancker, Y. Barrón, M. L. Rockoff, D. Hauser, M. Pichardo, A. Szerencsy, and N. Calmen, "Use of an electronic patient portal among disadvantaged populations," Journal of general internal medicine, vol. 26, pp. 1117-1123, 2011. Article (CrossRef Link) 


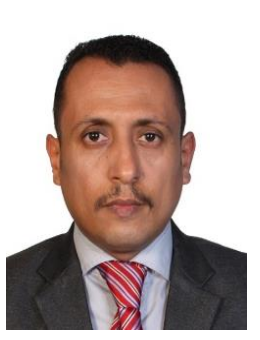

Muaadh Mukred is an Associate Fellow at the Faculty of Information Science and Technology, National University of Malaysia (UKM). He has a bachelor's degree from AlMustansiriah University, Iraq. He received a master's degree in computer science from the Faculty of Computing, Universiti Teknologi Malaysia and PhD from UKM. He has teaching experience with the Sana'a Community College, Yemen. His research interests are information system management, Electronic Records Management, Information Management, Information Governance, Knowledge Management, Information Systems, Electronic Records Management, Outcome Based Education, knowledge management, big data, and statistical data analysis (IBM SPSS, AMOS, NVIVO, and Smart PLS). He received the outstanding publication award and excellent academic achievement as an outstanding researcher in conjunction with the 46th Convocation Ceremony, from the Universiti Kebangsaan Malaysia, in 2018. Muaadh did his post-doctoral research on Information and Technology Management, Education, Cloud Computing, and Big Data Adoption for two years at the faculty of information science and technology - University Kebangsaan Malaysia (UKM), Malaysia. His articles have been published in reputed international journals. He has about thirteen years of fulltime work experience in lecturing, management, and academic research. He is an academic partner of three international universities, UKM, King Abdul-Aziz University, and the University of Technology in Iraq. Muaadh is also a reviewer of more than ten Web of Science journals and one of the main organizing committee members of the International Conference for the Reliable Information and Communication Technology and other International conferences. $\mathrm{He}$ supervises and examines many master and $\mathrm{PhD}$ students in different universities in Malaysia, Africa, and the Middle East.

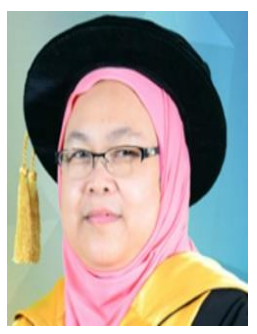

Zawiyah M. Yusof is a Professor of Records and Information Management at Faculty of Information Science and Technology, Universiti Kebangsaan Malaysia. She obtained her $\mathrm{PhD}$ in Records Management from Department of Information and Library Science, Aberystwyth, United Kingdom. Her research interests are Records and Information Management; Information Governance, Knowledge Management and Information Policy. Zawiyah has authored. She is a steering committee for International Research on Permanent Authentic Records in Electronic Systems (InterPARES) Project - Malaysia Team; research partner in InterPARES Trust (2013- 2018) research project; and technical committee for Records Management (Malaysia). She co-authored Issues in Records Management book with Robert W. Chell from West Glamorgan Archives and is a head of Information Governance Laboratory at her faculty. Zawiyah has been invited as keynote and guest speaker at international level and has also handled short courses to corporate and government institutions locally in records management. She has delivered her inaugural speech at her university in 2015 on topic Pengurusan Rekod dan Maklumat: Isu dan Cabaran (Records and Information Management: Issues and Challenges).

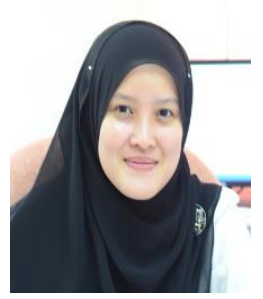

Umi Asma' Mokhtar is a senior lecturer of information science at School of Information Technology, Faculty of Information Science and Technology, Universiti Kebangsaan Malaysia. She was the recipient of the Oliver Wendell Holmes Travel Award from the Society of American Archivists in 2012. Her research interests are electronic records management, function-based classification, and information policy. Her papers have been published in international and national journals including the International Journal of Information Management and Records Management Journal. Currently, she is the coresearcher of InterPARES Trust project for Malaysian Team.

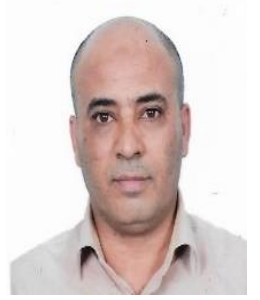

Burkan Hawash is a Ph.D. graduate from the Faculty of Information Science and Technology, Universiti Kebangsaan Malaysia. He was working in the Information Technology and Telecommunications Department in the Oil and Gas sector in Yemen, for more than 15 years. His research interests include information system management, electronic records management, and information security. Burkan has worked in TOTAL E\&P for 10 years as Telecom Supervisor. Burkan is an expert in data analysis through SmartPLS, SPSS, and R Programming. Burkan interest in archives, records management, digital transformation, and research. He possesses a Master's Degree in information security management and a Bachelor's degree in telecommunication engineering. 


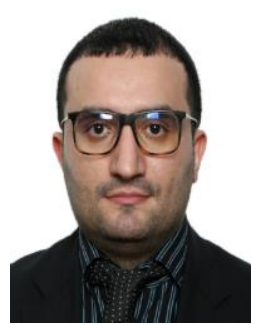

Ali Safaa Sadiq is a senior IEEE member and currently a faculty member and course coordinator of Artificial Intelligence and Robotics and a member at Wolverhampton Cyber Research Institute (WCRI) at Faculty of Science and Engineering, School of Mathematics and Computer Science, University of Wolverhampton, UK; he is also an adjunct staff at Monash University and Centre for Artificial Intelligence Research and Optimisation, Torrens University Australia. Ali has served as a lecturer at the School of Information Technology, Monash University, Malaysia. Previously he has also served as a senior lecturer at the Department of Computer Systems \& Networking Department, Faculty of Computer Systems \& Software Engineering, University Malaysia Pahang, Malaysia. Ali has completed his first degree in Computer Science at AL-Mustansiriyah University in 2004 , after that Ali has moved to Oman where he has joined the industry for 5 years working in the area of Computer Science and Networking. Afterwards, Ali has moved to Malaysia where he has done his $\mathrm{MSc}$ and $\mathrm{PhD}$ degrees in Computer Science from University Technology of Malaysia in 2011 and 2014 respectively. Ali has been awarded the ProChancellor Academic Award as the best student in his batch for both Masters and PhD. Ali has also been awarded the UTM International Doctoral Fellowship (IDF). He has published several scientific/research papers in well-known international journals and conferences. He was involved in conducting 5 research grants projects, whereby 3 of them are in the area of network and security and the others in analysing and forecasting floods in Malaysia. Recently he has involved as a co-investigator with a research project CYBERMIND that was funded $£ 91 \mathrm{k}$ by Innovate UK Cyber Academic Start-up Accelerator 2020. He has supervised more than5 $\mathrm{PhD}$ students and 6 Masters students as well as some other undergraduate final year projects. His current research interests include Wireless Communications, Network security and AI applications in networking.

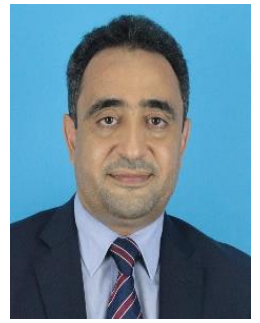

Waleed Abdulkafi Ahmed served as an academician and lecturer at Lincoln University, Malaysia. His scholastic achievements began with him obtaining a bachelor's degree in Mathematics from Sana'a University, Yemen, after which he proceeded to obtain his Master's degree in Management from the Faculty of Management of the International Islamic University, Malaysia (IIUM). His highest academic achievement was a $\mathrm{PhD}$ in Management from University Teknologi (MARA), Shah Alam, Malaysia, with the focus of interest being on Strategic Planning, Organization Performance, Strategic Management, Resource Management, Outcome-based Education, E-records Management, Statistical Data Analysis (IBM SPSS, AMOS and Smart PLS), and Quality Assurance. Consistent with the above achievements is his experience and expertise in the educational field for over two decades, beginning with his tenure as an Education Advisor in the Amran Government, under the Ministry of Education of Yemen. He held a position with innumerable responsibilities that had direct contributions to the governorate's school's performance. During 2001-2005, he held the position, by selection, as the Principal of Alzubairy Secondary School, during which he obtained the award for the "Best Principal Award" from the Ministry of Education. Added to his repertoire of achievements, Waleed actively works as a human society activist in his role as the Deputy Secretary of Human Relief and Development Society (INSAN). His current position as the Academic Director of the International Modern Arabic School (IMAS), Malaysia, provides him with the opportunities and the experience to assist in driving the school towards the right strategic direction, while maintaining high and quality academic standards. His tenure in IMAS has been more than fruitful in light of the high-level academic activities, scholastic quality, and outstanding external examination outcomes. 